\title{
Oil filling history of the Bashituo Oilfield in the Markit Slope, SW Tarim Basin, China
}

\author{
Cui Jingwei1 ${ }^{1,2 *}$, Wang Tieguan², Li Meijun ${ }^{2}$, Ou Guangxi², Geng Feng ${ }^{3}$ and \\ Hu Jian ${ }^{2}$ \\ ${ }^{1}$ Research Institute of Petroleum Exploration \& Development, PetroChina, Beijing 100083, China \\ ${ }^{2}$ Key Laboratory of Petroleum Resources and Prospecting, China University of Petroleum, Beijing 102249, China \\ ${ }^{3}$ Northwest Branch Company, SINOPEC, Urumqi, Xinjiang 830011, China \\ (C) China University of Petroleum (Beijing) and Springer-Verlag Berlin Heidelberg 2013
}

\begin{abstract}
The Markit Slope is an important area for the petroleum exploration in the Tarim Basin. Elucidation of the oil filling history of discovered oilfields has great significance for recognizing the accumulation processes of the whole region. Using molecular geochemistry, fluid inclusion techniques and basin modeling, we studied the oil filling process of the Bashituo Oilfield that is located in the west of the Markit Slope. The molecular migration indexes, such as the methyldibenzothiophene ratio (4-/1-MDBT), trimethylnaphthalene ratio (TMNr) and pyrrolic nitrogen compounds content, decrease from west to east, indicating that the charging direction and migration pathways are from west to east. Lithological analysis and homogenization temperatures of saline fluid inclusions accompanied with oil fluid inclusions suggest that two charging periods occurred in the Devonian oil reservoir. Combining the burial history and heating history of well BT4, Basinmod 1D software modeling shows the two oil filling periods are from 290 $\mathrm{Ma}$ to $285 \mathrm{Ma}$ and from $10 \mathrm{Ma}$ to $4 \mathrm{Ma}$, respectively, and later oil filling dominates. This study may be helpful to understand the accumulation process and provide useful references for oil and gas exploration in the Markit Slope.
\end{abstract}

Key words: Oil migration direction, filling time, fluid inclusion, basin modeling, Tarim Basin

\section{Introduction}

Petroleum charging direction and accumulation period have been of great importance in petroleum accumulation studies in the North Sea Oilfield of Europe and Tahe Oilfield of the Tarim Basin in China (Larter et al, 1996; Li et al, 1994; 2000; Wang et al, 2008). Identification of charging direction mainly relies on molecular geochemistry and the principals are easily understood. One depends on the increasing maturity of source rocks, and the other is the differentiation between organic molecules on mineral surfaces during migration. Preconditions and limitation in the application of traditional methods include entrapment formation, main generation and expulsion period in source rocks, reservoir saturation pressure, oil-water interface tracing and event geology. A preferable way of interpreting and defining the accumulation period is combining fluid inclusions and singlewell modeling.

National key scientific and technological projects have estimated the total petroleum resources of the Markit Slope to be between $38 \times 10^{8} \mathrm{t}$ and $44 \times 10^{8} \mathrm{t}$ while some experts suggest the resources could even be $67 \times 10^{8} \mathrm{t}$ in the Southwest

*Corresponding author. email: cuijingwei@petrochina.com.cn Received February 14, 2012
Depression of the Tarim Basin (Liu and Yuan, 2002). A number of scholars and oil companies have ranked the Markit Slope as the most prospective petroleum exploration plays in the Southwest Depression for multiple source layers and oil shows (Cui et al, 2012). However, only a few petroleum reservoirs have been discovered, including the Bashituo Oilfield and Hetian River Gasfield. The Paleozoic strata of the Markit Slope are deposited on a passive continental margin, but are quite different from other passive continental margin basins which have great petroleum resources, such as the North Sea Basin and the Mexico Basin (Dong and Xiao, 1998; Zhou et al, 2006). Multiple production layers, and diverse oil and gas occurrences make it quite complex to reconstruct the oil filling history and determine exploration targets. Studies of charging directions can only be seen in wells Qun4 and Qun5, and accumulation period study has also been questioned because of geothermal information constraints and few fluid inclusions measuring spots (Zhao and Zhang, 2007; Liu, 1997).

Our previous works show that oils from the Markit Slope can be divided into two oil families by molecular geochemistry and isotopic value. The oils from the Bashituo Oilfield are the same oil family, except for the oil from well Qu 1 (Cui et al, 2011). This paper focuses on the oil filling by molecular tracing research. Besides, combining 
the burial history, heating history, lithological analysis and homogenization temperature in reservoir fluid inclusions, we model and define the accumulation time of Devonian production layers of BT4 well in the Bashituo Oilfield by using Basinmod 1D software (PRA company). Definition of oil filling direction and accumulation time aids in recognizing the accumulation process and directing further exploration.

\section{Sampling and apparatuses}

\subsection{Geological setting and sampling}

As a second structural unit of the Southwest Depression in the Tarim Basin, the Markit Slope has passive continental margin sediments in the Paleozoic strata and is located on the slope and uplift belts in Mesozoic strata. The Bashituo Oilfield is a structural anticline with its strike of EW (Fig. 1) located in the west of the Markit Slope. This anticline was accompanied with a north-dip thrust-fault whose dip angle decreases from top to bottom (Zhou et al, 2006). The current production layers are the Devonian Donghetang Formation $\left(\mathrm{D}_{3} \mathrm{~d}\right)$ and Keziertage Formation carbonates and
Carboniferous limestones of the Bachu Formation. Light oils were abundant in fracture zones and spread in several members and beds, showing a complex accumulation process.

The crude oil density of Bashituo Oilfield ranges from 0.712 to $0.843 \mathrm{~g} / \mathrm{cm}^{3}$, the kinematic viscosity is from 0.51 to $6.58 \mathrm{~mm}^{2} / \mathrm{s}$, its wax content varies from $0.06 \%$ to $9.75 \%$, the sulfur content is from $0.06 \%$ to $0.43 \%$, the freezing point is from -26 to $-35{ }^{\circ} \mathrm{C}$, the initial boiling point is from 46.4 to $200{ }^{\circ} \mathrm{C}$, the content of colloid and asphalt is $0 \%-7.1 \%$. These physical properties indicate that the oils are low viscosity, low wax to waxy, low sulfur and light oils (Fig. 2). Sandstone samples from $\mathrm{D}_{3} \mathrm{~d}$ in well BT4 have been collected and diagenesis features were examined by electron microscopy. The homogenization temperatures of 232 selected points within $20 \mathrm{~m}$ in depth have been measured in saline fluid inclusions accompanied with oil and gas fluid inclusions.

\subsection{Apparatus and conditions}

The oils were quantitatively separated into saturated, aromatic, resin and asphaltene fractions. The saturated and aromatic fractions examined by GC and GC/MS analysis
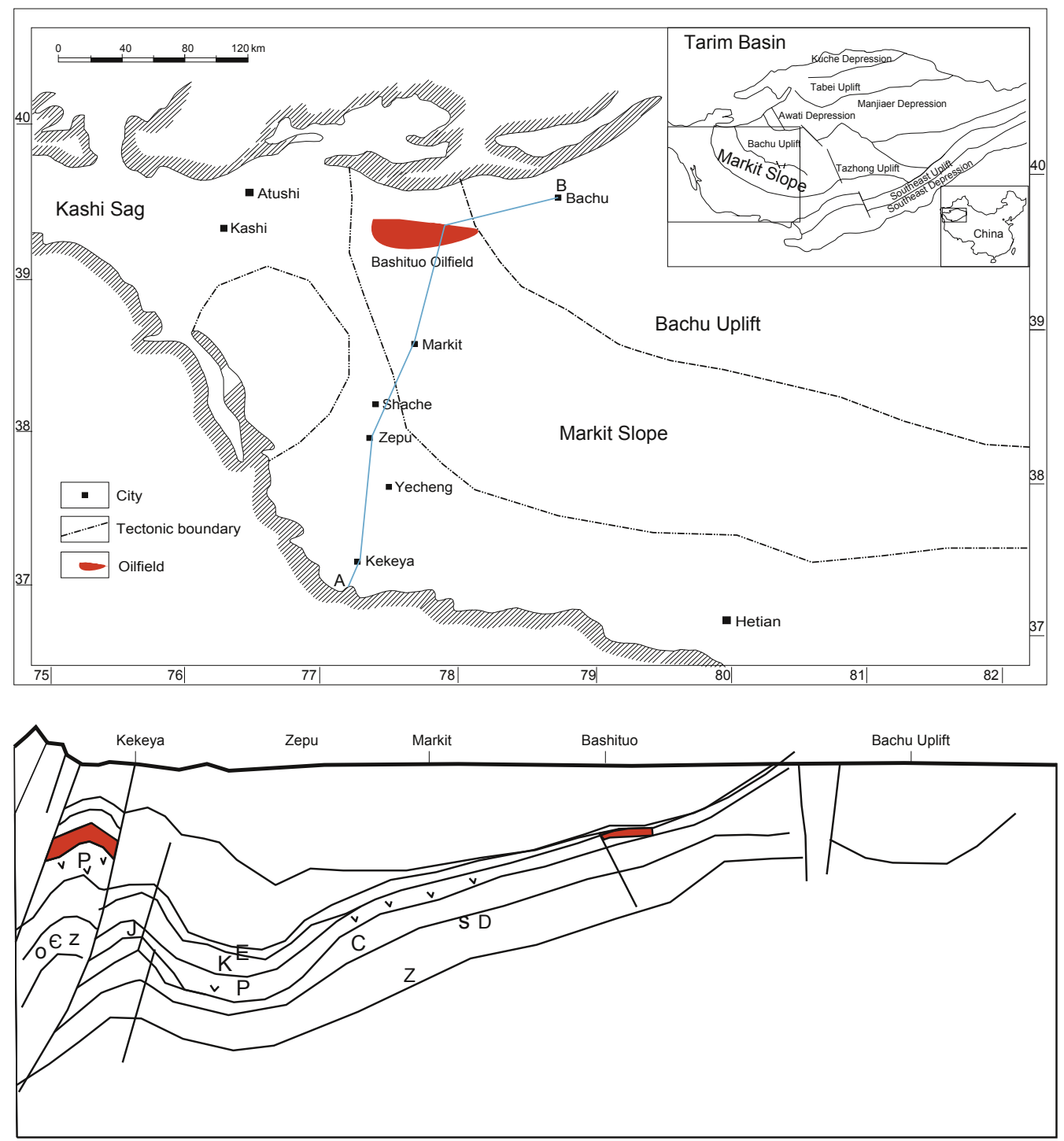

Fig. 1 Tectonic division, oilfield distribution and cross section 


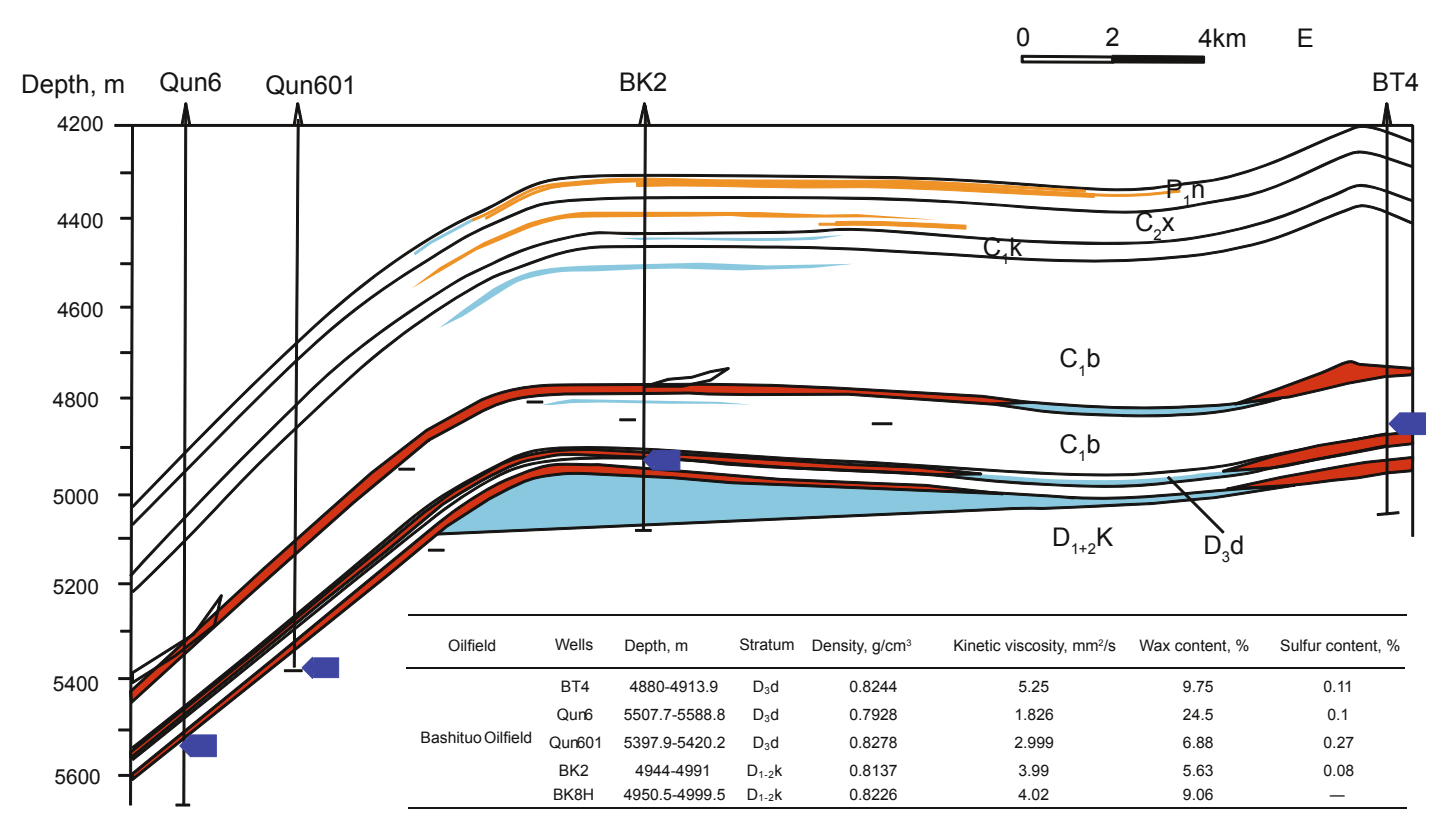

Fig. 2 Reservoir profile of the Bashituo Oilfield and the physical characteristics of oils

respectively. Full-scan GC-MS was performed using an Agilent 5975i spectrometer interfaced to a 6890 gas chromatograph equipped with a $60 \mathrm{~m}$ fused silica capillary column $(0.32 \mathrm{~mm}$ in inner diameter, $0.25 \mu \mathrm{m}$ in film thickness) and NIST2.0 searching database. Helium was used as the carrier gas and the injector was held at $300{ }^{\circ} \mathrm{C}$. The oven temperature was initially set at $80^{\circ} \mathrm{C}$, and programmed to increase to $300{ }^{\circ} \mathrm{C}$ at $3{ }^{\circ} \mathrm{C} / \mathrm{min}$, with a final hold of 15 minutes. A scan from 50 to $550 \mathrm{amu}$ was used in the mass spectrometric analysis. Electron ionization was employed (70 $\mathrm{eV}$ ) and the emission current was $300 \mu \mathrm{A}$. Fluid inclusion examination was undertaken using a LINKAM THMS600 with heating/freezing stage 7035 according to EJ/T 1105-1999 temperature measurement standard for mineral inclusions. The room temperature and humidity were $20{ }^{\circ} \mathrm{C}$ and $25 \%$, respectively.

\section{Results and discussion}

\subsection{Oil filling direction and pathway}

Oils from the Baishituo Oilfield have been categorized as light oils with low resin content. Based on the dibenzothiophenes (DBTs) and TMNr indexes, we carried out the migration tracing study on the Keziertage and Donghetang Formations. The Bashituo Oilfield is comparatively small and the oils of the Lower and Middle Devonian Keziertage Formation, Upper Devonian Donghetang Formation, and Lower Carboniferous Bachu Formation belong to the same oil family (Cui et al, 2011). Detailed migration tracing may be difficult because of limited availability of oil samples. However, the migration directions and trends can be determined. In this paper the migration directions of oils from the Keziertage and Donghetang Formations have been studied.

Molecular thermal stability and adsorption mechanisms can interpret DBT ratios to determine petroleum charging directions. Thermal stability varies in different substitutions of benzene rings. Alkyl analogs have been reported the most stable on the $\mathrm{C}-4(\beta-)$ position, and the least stable on the $\mathrm{C}-1(\alpha-)$ position. Therefore, the 4-/1-MDBT ratio increases because of the relative increase of 4-MDBT with increasing maturity. The adsorption mechanism could be the hydrogen bond between lone pair electrons of the sulfur atom in thiophene and hydrogen atom of the surrounding formation minerals. A fractionation effect occurs in the adsorption of thiophene molecules (Wang et al, 2004). Being utilized successfully to trace migration directions of Ordovician reservoirs in the Tahe Oilfield, 4-/1-MDBT has been considered as an effective molecular migration index (Wang et al, 2008). Well Qun 6 in the Bashituo Oilfield exhibits a 4-/1-MDBT value of 9.8. This ratio decreases from west to east, 7.7 in well Qun 601, 5.6 in well BK8H and 6.4 in well BK2 and 4.7 in well BT4 (high spot in the east), indicating its migrating direction from west to east (Fig. 3).

The principle for tracing charging direction using the $1,3,6-\mathrm{TMNr} /(1,3,6-\mathrm{TMNr}+1,2,5-\mathrm{TMNr})$ ratio is that $1,2,5-$ $\mathrm{TMNr}$ decreases with an increase of maturity because of spatial steric hindrance and stability differences of various substitutions $(\beta->\alpha-)$. The petroleum charging direction is consistent with the decreasing trend of $\mathrm{TMNr}$, which is also the downward trend of maturity. Reflected in Fig. 4, the TMNr index in well Qun6 is 0.87 and in well Qun601 is 0.84, decreasing with the west-to-east geological axis. TMNr is 0.78 in well $\mathrm{BK} 2, \mathrm{BK} 8 \mathrm{H}$, and 0.53 in well $\mathrm{BT} 4$, indicating the charging direction from west to east. The TMNr index in well BT4 is unusually low, which could result from oil in well BT2 being a mixture from more than one source. The content of pyrrolic nitrogen compounds is also suggested as a molecular migration index (Larter et al, 1996; Li et al, 2000). This also has a decreasing trend from west to east.

\subsection{Oil filling times}

\subsubsection{Evidence from molecule geochemistry}

Complete and successive sequences of $n$-alkanes have 


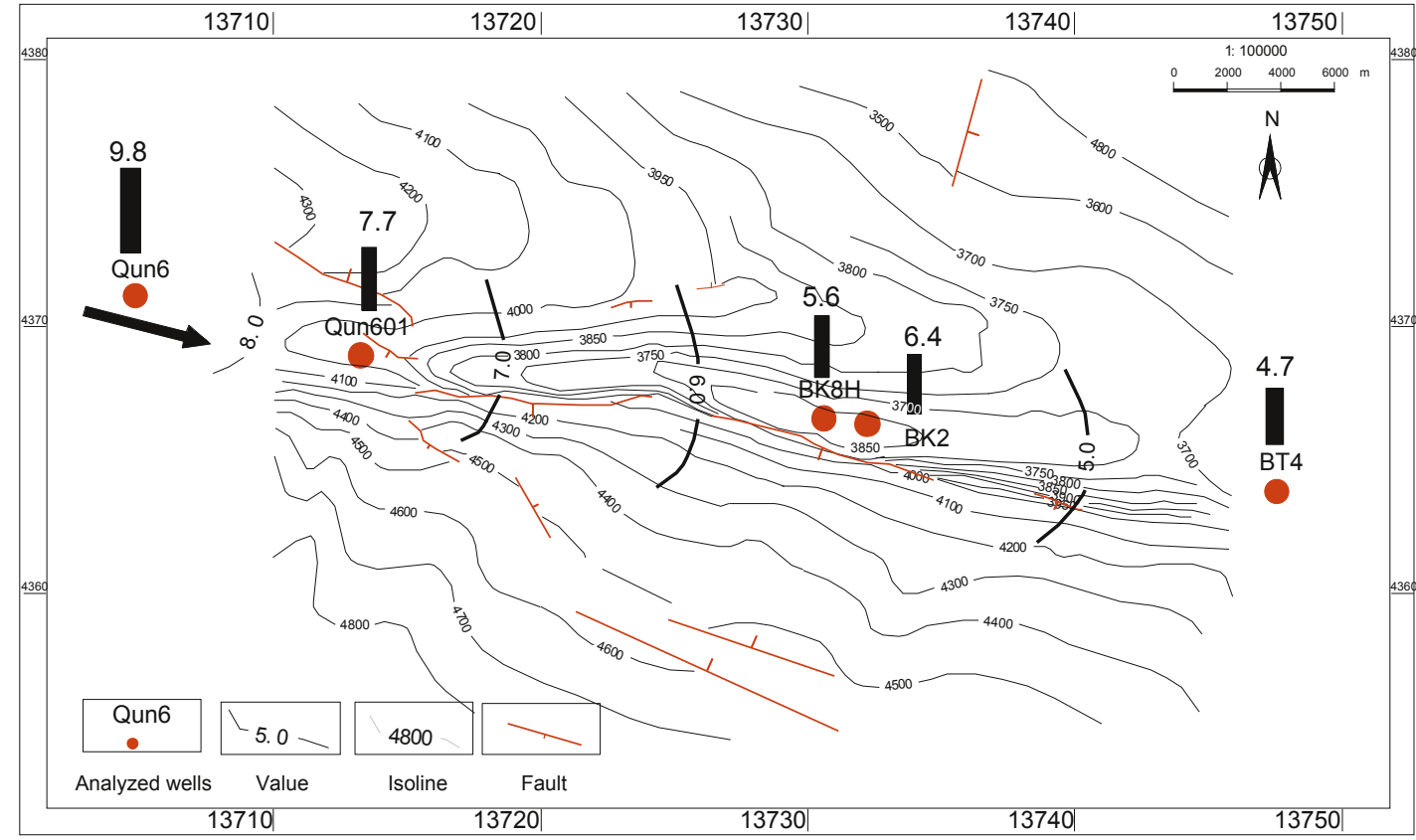

Fig. 3 4-/1-MDBT ratio charging figure of Devonian reservoirs in the Bashituo Oilfield

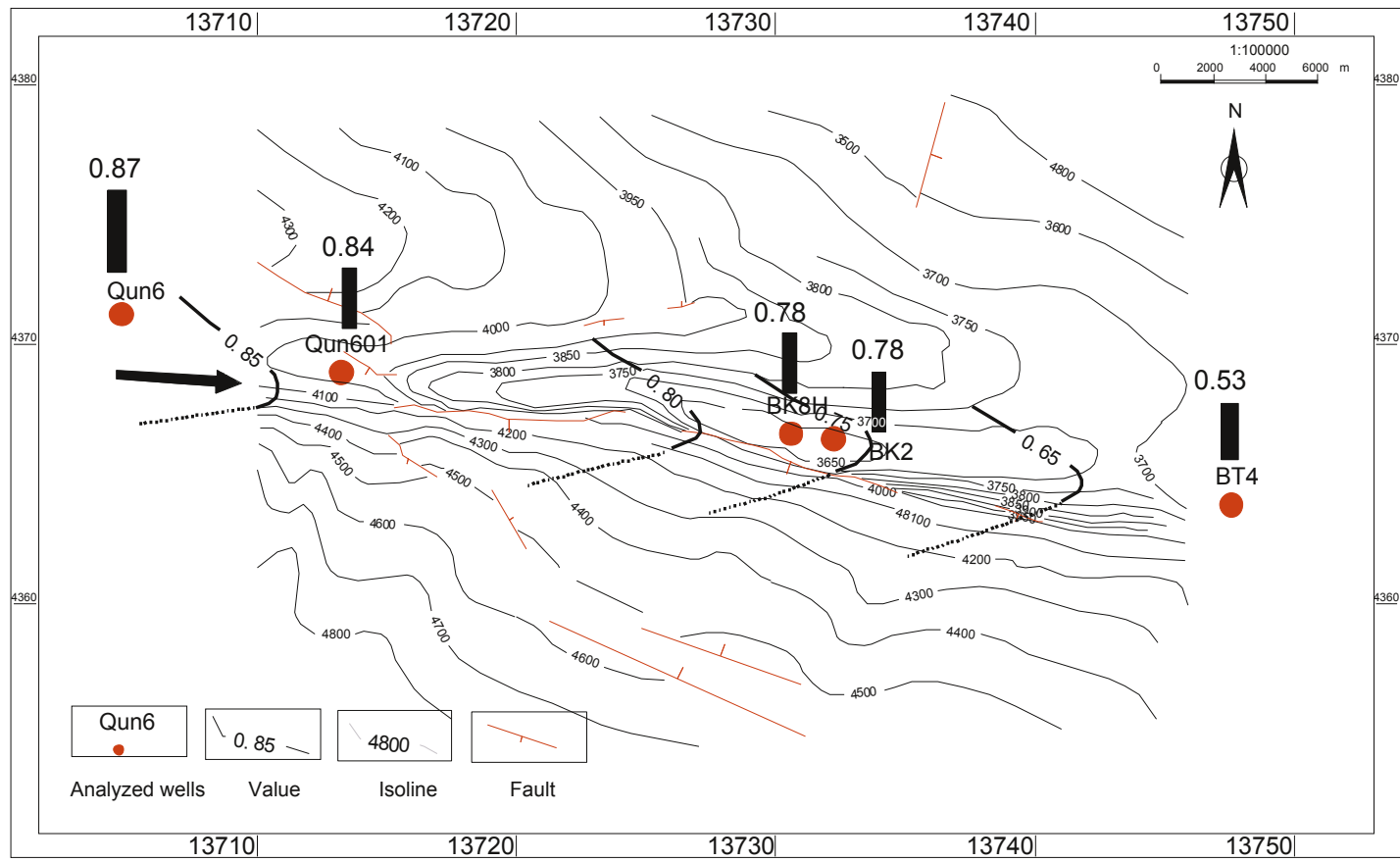

Fig. $4 \mathrm{TMNr}$ charging figure of Devonian reservoirs in the Bashituo Oilfield

been detected in the light oils of the Bashituo Oilfield and simultaneously 25-norhopane and UCM (unresolved compound mixture) were detected (Fig. 5). According to Peters and Moldowan (1993), these two sequences may not coexist in the biodegrading sequences. At least two periods of oil charging are proposed for the Bashituo Oilfield.

\subsubsection{Evidence from fluid inclusions}

Well BT4 is situated in the east of the east high point of the Bashituo Anticline. The sandstone cores (medium grain sandstone) of the Upper Devonian Donghetang Formation were collected within $20 \mathrm{~m}$ for fluid inclusion analysis. The intergranular pores without oil and fluorescence are extensively filled with thin and stringy black carbonaceous asphalt. Several specific fields of view suggested that pores are filled with non-fluorescing carbonaceous asphalt. Secondary enlargement of quartz grain widely spreads, but the quartz grains whose intergranular pores have been filled previously with carbonaceous asphalt show weak diagenesis and secondary enlargement. Some intergranular pores are filled with postdiagenetic calcite.

Two periods of oil and gas fluid inclusions exist in the sandstones. The first period contains high abundance of oil and gas fluid inclusions with 70\% liquid hydrocarbon inclusions and $30 \%$ gaseous-liquid hydrocarbon inclusions. The liquid hydrocarbon inclusions are rose beige, brown, light yellow to deep puce, with light green to green fluorescence 

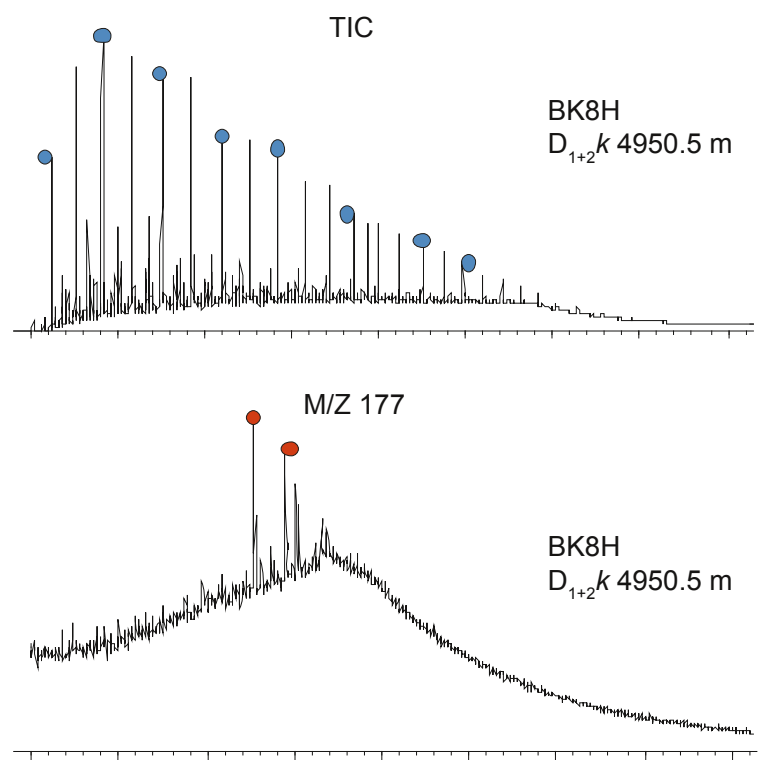

n-alkanes
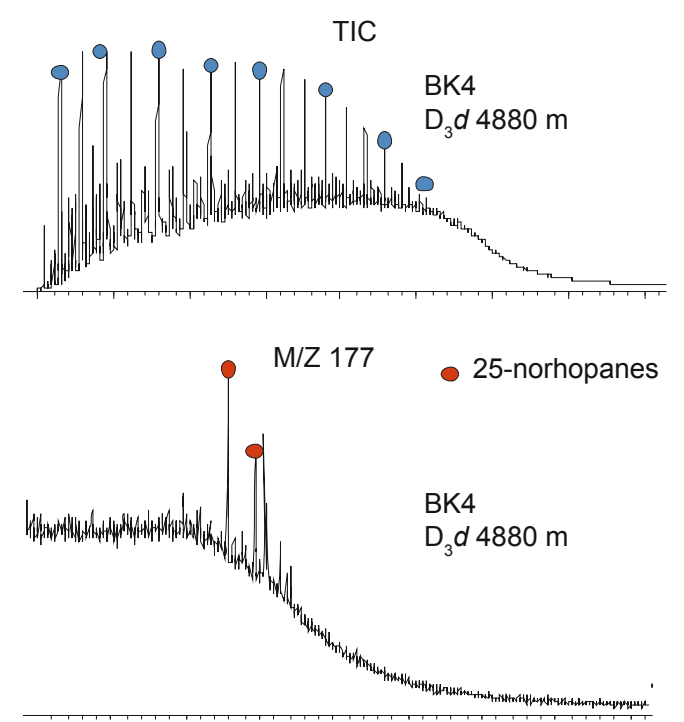

Fig. 5 Total ion count (TIC) and M/Z 177 typical mass spectrum of oils in the Bashituo Oilfield

and are distributed along the early diagenesis tiny fracture of quartz grains. The second period contains a low abundance of oil and gas fluid inclusions with 10\% liquid hydrocarbon inclusions and 90\% gaseous-liquid hydrocarbon inclusions. The liquid hydrocarbon inclusions are light yellow and light green with light green fluorescence and are distributed along the fracture cutting quartz grains and enlargement rims (Fig. 6). Based on the fluorescence color, we think that the early fluid inclusions are of low maturity and the late fluid inclusions are of high maturity (Przyjalgowski et al, 2005;

\section{Blamey and Ryder, 2009).}

The homogenization temperatures of saline fluid inclusions accompanying the oil and gas fluid inclusions are between 65 and $121^{\circ} \mathrm{C}$. Based on the column diagram of the temperatures, we can delineate two accumulation periods in the saline fluid inclusions: the first period of temperatures is $80-87{ }^{\circ} \mathrm{C}$ and the second is $95-100{ }^{\circ} \mathrm{C}$ (Fig. 7). The homogenization temperature would be quite close to the trapping temperature provided there has been no later re-equilibrating process in the fluid inclusions which
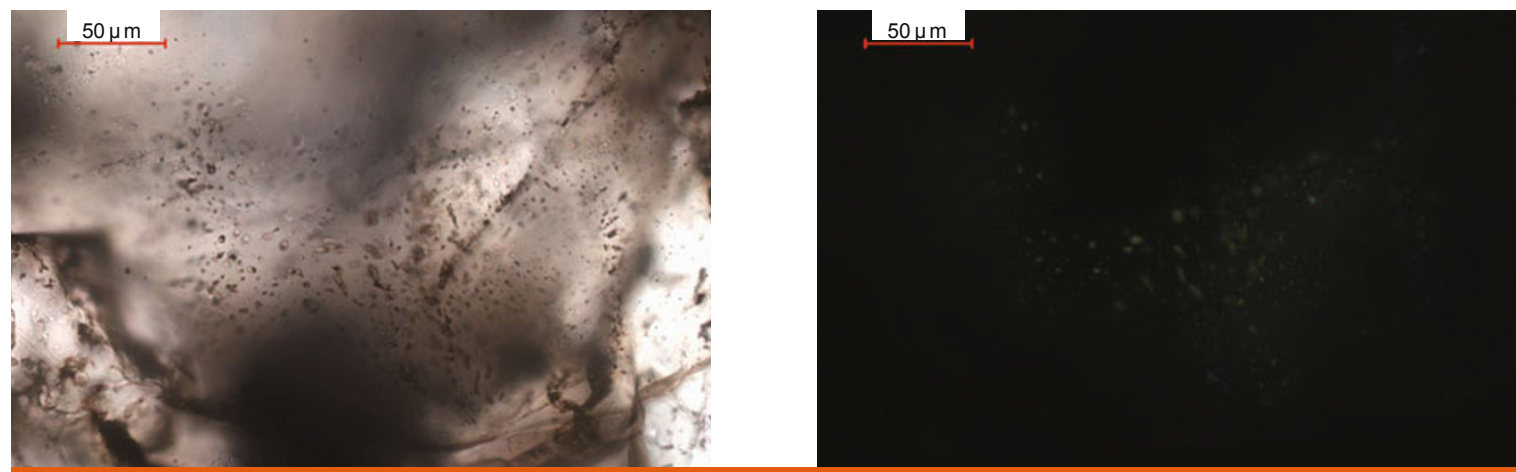

The first period: distributed along the early diagenesis tiny fracture of quartz grains
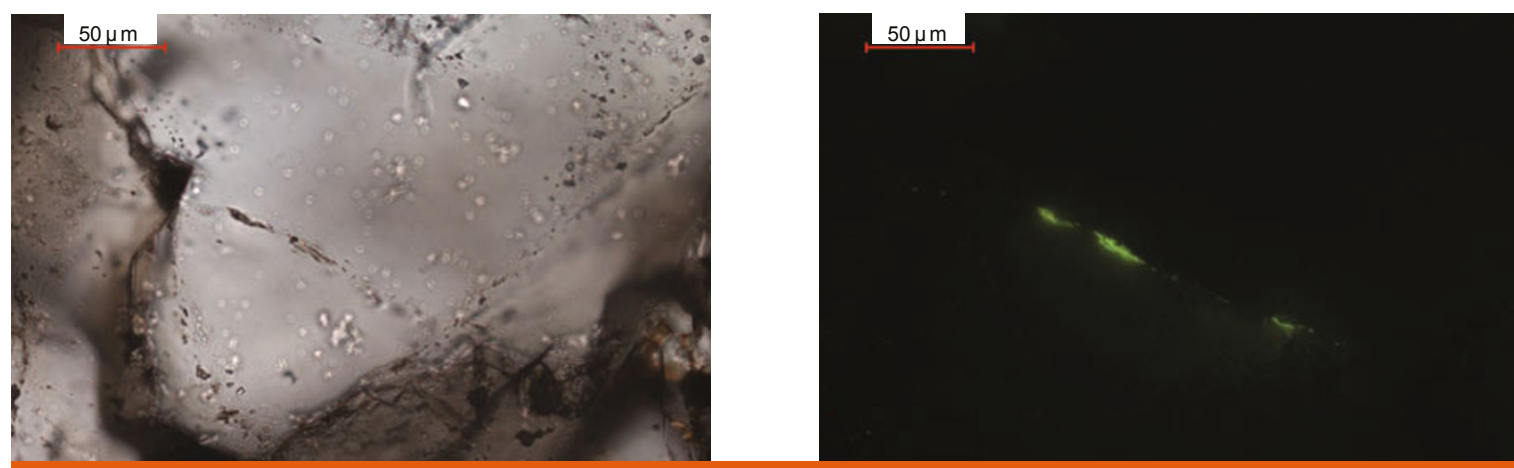

The second period: distributed along the fracture cutting quartz grains and enlargement rims

Fig. 6 Polarized light and fluorescence pictures of two periods of oil \& gas inclusions of $\mathrm{D}_{3} \mathrm{~d}$ sandstones in well BT4 at a depth of $4,990 \mathrm{~m}$ in the Bashituo Oilfield 
had been saturated with gas (Hanor, 1980; Emery and Robinson, 1999). It is generally believed that in the layers containing oil and gas fluid inclusions, the water inclusions with the same occurrence are saturated with gas. The homogenization temperature is approximately the trapping temperature (Nedkvitne et al, 1993). Hence, we could use the homogenization temperature to determine the accumulation period (see below)

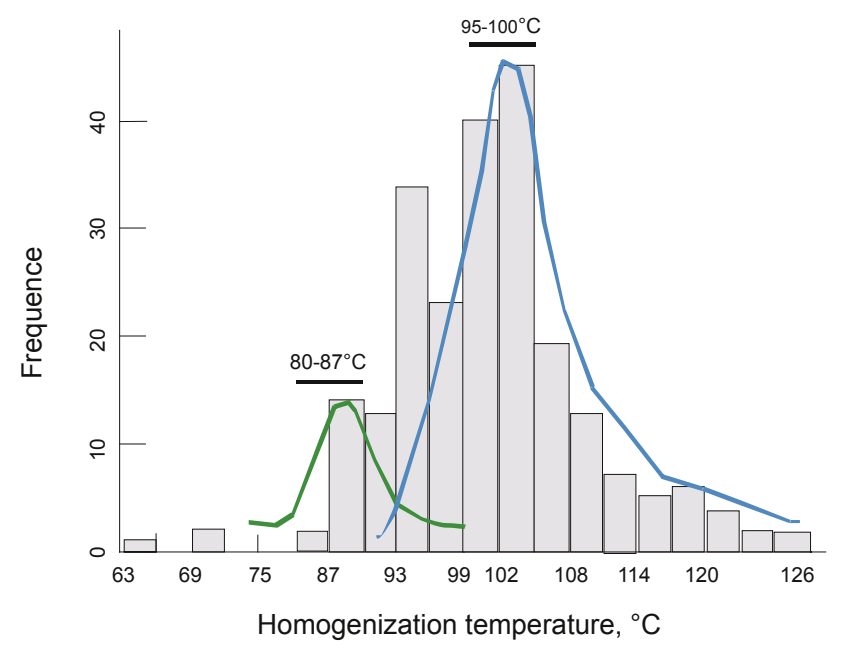

Fig. 7 Column diagram of homogenization temperatures in saline fluid inclusions accompanying the oil and gas fluid inclusions from 4,884 to $4,906 \mathrm{~m}$ in $\mathrm{D}_{3} \mathrm{~d}$ in well BT4 in the Bashituo Oilfield

\subsection{Accumulation time determined by Basinmod 1D}

We carried out basin modeling to understand the whole process of migration and accumulation. One of the most valuable basin modeling input parameters is the thermal history, so we need to use heat flow or geothermal gradient to obtain thermal history. Previous works suggested that the Tarim Basin was once a "cool basin" with low terrestrial heat flow. Nowadays, the heat flow in the Markit Slope is about $45-50 \mathrm{~mW} / \mathrm{m}^{2}$ and in the foreland of southwestern Tarim Basin it is about $40-45 \mathrm{~mW} / \mathrm{m}^{2}$ (Table 1) (Wang et al, 1995a; $1995 \mathrm{~b}$; 1996). We chose $45-50 \mathrm{~mW} / \mathrm{m}^{2}$ for modeling and adjust with the actual measurement of $R_{\mathrm{o}}$ values. Moreover, a single terrestrial heat flow could not adequately explain the evolution of the Uplift of the Northern Tarim during the modeling ( $\mathrm{Li}$ et al, 2010). It is necessary to consider variation of terrestrial heat flow with time. Terrestrial heat flow was high during the early Ordovician, decreased in early Carboniferous, rose abruptly at the time of the Permian volcanic activity and then decreased to the current level.

Table 1 Terrestrial heat flow of the Tarim Basin (unit: $\mathrm{mW} / \mathrm{m}^{2}$ )

\begin{tabular}{ccccc}
\hline $\begin{array}{c}\text { Uplift of } \\
\text { Northern } \\
\text { Tarim }\end{array}$ & $\begin{array}{c}\text { Uplift of } \\
\text { Middle Tarim }\end{array}$ & $\begin{array}{c}\text { Foreland of } \\
\text { Southwest Tarim }\end{array}$ & Bachu-Markit & References \\
\hline $38-52$ & $60-50$ & 42 (Yecheng) & 50 & $\begin{array}{c}\text { Wang et al, } \\
1995 \mathrm{a} ; 1996\end{array}$ \\
$40-45$ & $65-72$ & $30-40$ & $45-50$ & $\begin{array}{c}\text { Wang et al, } \\
1995 \mathrm{a}\end{array}$ \\
\hline
\end{tabular}

Other crucial input parameters in the modeling are the unconformable plane and erosion thickness. The Tarim Basin has been defined as a superimposed basin and underwent several structural movements in geological history, resulting in multiple strata erosion and unconformable or disconformable planes. In well BT4 which is located in a high geological site, only the strata above the Devonian are penetrated. The closely related contact planes include the bottom of the Upper Devonian, bottom of the Permian and the Triassic, Jurassic, Cretaceous, and Paleogene. The unconformity between Permian and Neogene is the most important one, and the Neogene Anju'an Formation $\left(\mathrm{N}_{1} \mathrm{a}\right)$ and Lower Permian contact with each other directly with the absence of Upper Permian, Triassic, Jurassic, Cretaceous and Paleogene. The restoration study of the erosion thickness of the Permian of the southwestern Tarim has been carried out, which suggested that the thickest erosion occurs in the Kashi Depression (over 1,200 m) and the erosion thickness is 1,000 m near well BT4 (Mou et al, 2002). We used strata data provided by the Northwest Oilfield Branch, SINOPEC and paleogeothermal and erosion thickness data from previous papers.

\subsection{Delineating the accumulation periods}

According to the above program, the results should be corrected with the actual measurement of $R_{\mathrm{o}}$ (Fig. 8 the black cross marks) and the curve of $R_{\mathrm{c}}$ (Fig. 8 the right red line) to validate the reliability of the reconstructed burial and thermal histories. We drew the conclusion that two accumulation and charging periods occurred in the $\mathrm{D}_{3} \mathrm{~d}$ reservoir in well BT4 of the Bashituo Oilfield. The first accumulation period is early Permian (290-285 Ma) and the second one is Miocene and Pliocene (10-4 Ma). This study shows good agreement with the previous research of well Qun4 in this oilfield (Liu and Song, 2006).

\section{Conclusions}

Molecular migrating indexes (MMI), such as 4-/1-MDBT and $\mathrm{TMNr}$, show that the maturity decreases from west to east, indicating the oil charging was from the west to the east in the Devonian formations of the Bashituo Oilfield. That is consistent with the top surface structure of the Devonian.

Lithological analysis and homogenization temperature of the saline fluid inclusions accompanied with the oil and gas fluid inclusions suggest two accumulation periods. Combining the burial history and thermal history, we used the Basinmod 1D software to estimate the accumulation time and draw the conclusion that the first period is from $290 \mathrm{Ma}$ to $285 \mathrm{Ma}$ (early Permian) and the second period is from $10 \mathrm{Ma}$ to $4 \mathrm{Ma}$ (Miocene to Pliocene) and the later accumulation dominates.

The Bashituo Oilfield is small, and the BT4 exploration well is consistent with the nearby well Qun4 on oil quality, molecular composition and filling history. It is rational for us to extrapolate that the oil wells in Devonian $\left(\mathrm{D}_{3} \mathrm{~d}\right.$ and $\left.\mathrm{D}_{1+2} \mathrm{k}\right)$ are accumulated in the same charging period.

\section{Acknowledgements}

We thank two anonymous reviewers and editors for their suggestions, and Northwest Oilfield Branch Company, SINOPEC, for providing samples, data access and permission to publish this work. This work is financially supported by the 

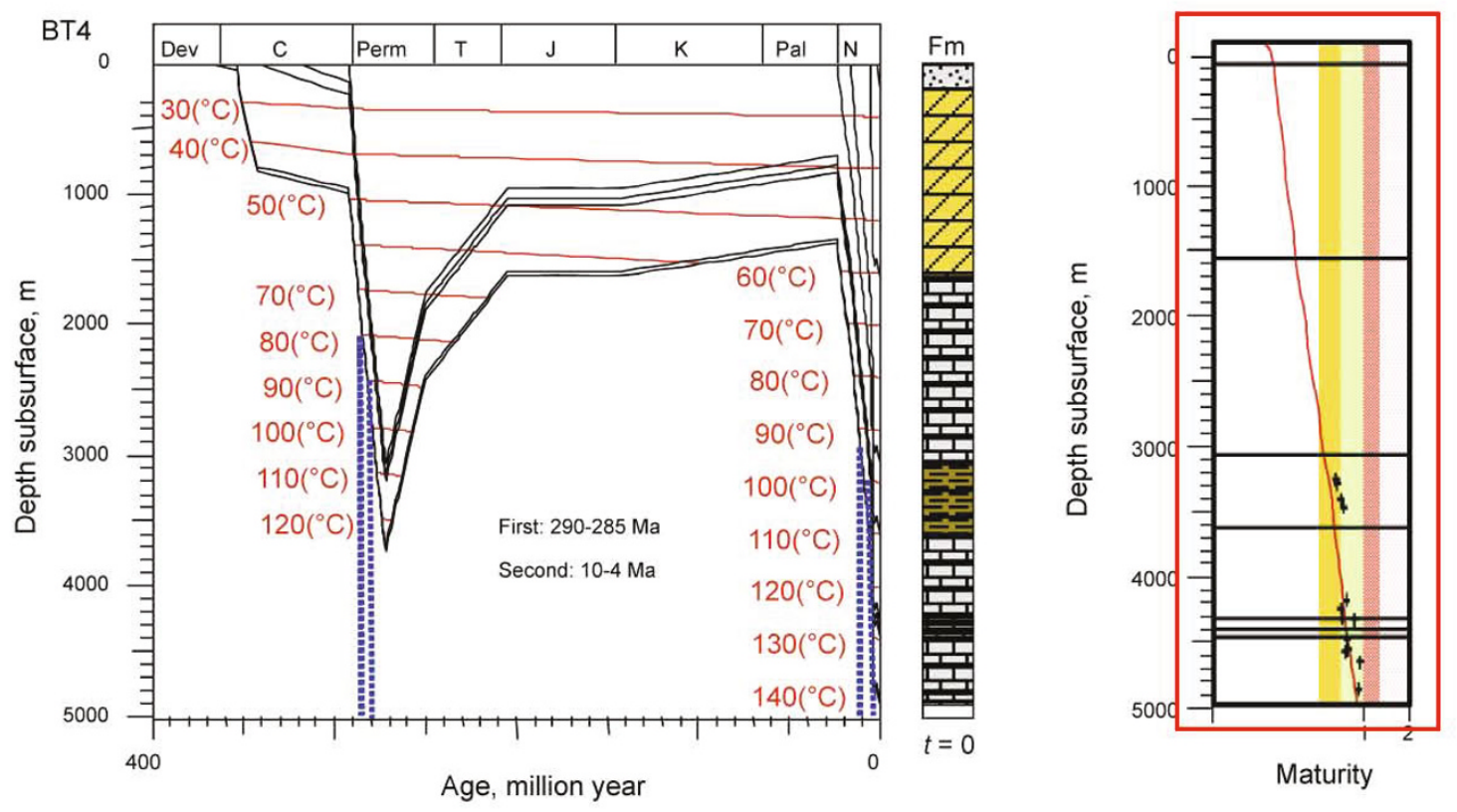

Fig. 8 Burial and thermal history of $\mathrm{D}_{3} \mathrm{~d}$ in well BT4 in the Bashituo Oilfield

Natural Science Foundation of China (Grant No.40972089), the Foundation of the State Key Laboratory of Petroleum Resources and Prospecting (Grant No.PRPDX2008-01). We also would like to thank Zhu Lei for his laboratory work and Shi Shengbao for the GC-MS analysis.

\section{References}

Blamey N J F and Ryder A G. Hydrocarbon fluid inclusion fluorescence: A review. Reviews in Fluorescence. 2009. 299-334

Cui J W, Wang T G and Li M J. Geochemical characteristics and oil family classification of crude oils from the Markit Slope in the southwest of the Tarim Basin, Northwest China. Chinese Journal of Geochemistry. 2011. 30(3): 359-365

Cui J W, Wang T G, Zou C N, et al. Geochemical characteristics and oilsource correlation of oil-sand extracts of Kelatuo Anticline in the northern Kashi Sag, NW Tarim Basin, China. Energy, Exploration \& Exploitation. 2012. 30(4): 609-622

Dong D Z and Xiao C G. Petroleum Geology and Oil and Gas Resources of the Southwest Depression of the Tarim Basin. Beijing: Petroleum Industry Press. 1998. 25-55 (in Chinese)

Emery D and Robinson A. Inorganic Geochemistry: Applications to Petroleum Geology. Translated by Wang T G, Jin Z K, Wang D R, et al. Beijing: Petroleum Industry Press. 1999. 25-70

Hanor J S. Dissolved methane in sedimentary brines: Potential effect on PVT properties of fluid inclusions. Economic Geology. 1980. 75(4): 603-617

Larter S R, Bowler B F J, Li M W, et al. Molecular indicators of secondary oil migration distances. Nature. 1996. 383: 593-597

Li M J, Wang T G, Chen J F, et al. Paleo-heat flow evolution of the Tabei Uplift in the Tarim Basin, northwest China. Journal of Asian Earth Sciences. 2010. 37(1): 52-66

Li M W, Later S R, Frolov Y B, et al. Adsorptive interaction between nitrogen compounds and organic and/or mineral phases in subsurface rocks. Models for compositional fractionation of pyrrolic nitrogen compounds in petroleum during petroleum migration. Journal of High Resolution Chromatography. 1994. 17(4): 230-236

Li M W, Xiao Z Y, Snowdon L, et al. Migrated hydrocarbons in outcrop samples: Revised petroleum exploration directions in the Tarim Basin. Organic Geochemistry. 2000. 31(6): 599-603

Liu L F. Geochemical study of pyrrole nitrogen compounds in crude oil of Qun4 in the Tarim Basin. Acta Sedimentologica Sinica. 1997.
15(2): 184-187 (in Chinese)

Liu L J and Yuan W X. Petrospect and prospect of oil-gas exploration in the Southwestern Tarim Basin. Xinjiang Geology. 2002. 20(suppl): $1-5$ (in Chinese)

Liu S B and Song Y. Geochemical characteristics of fluid inclusions in Qungkurqack structural belt, Tarim Basin. Xinjiang Petroleum Geology. 2006. 27(2): 142-145 (in Chinese)

Mou Z H, Tang Y and Cui B F, et al. Erosion thickness restoration in southwest Tarim Basin. Acta Petrolei Sinica. 2002. 23(1): 40-44 (in Chinese)

Nedkvitne T, Karlsen D A, Bjorlykke K, et al. Relationship between reservoir diagenetic evolution and petroleum emplacement in the Ula field, North Sea. Marine and Petroleum Geology. 1993. 10(3): 255-270

Peters K E and Moldowan J M. The Biomarker Guide: Interpreting Molecular Fossils in Petroleum and Ancient Sediments. Prentice Hall Inc. 1993. 55-75

Przyjalgowski M A, Ryder A G, Feely M, et al. Analysis of hydrocarbonbearing fluid inclusions (HCFI) using time-resolved fluorescence spectroscopy. SPIE. 2005. 58(26): 173-184

Wang J, Wang J A and Shen J Y. Heat flow in Tarim Basin. Earth Science-Journal of China University of Geoscience. 1995a. 20(4): 399-404 (in Chinese)

Wang L S, Li C and Shi Y S. Distribution of terrestrial heat flow density in Tarim Basin, Western China. Chinese Journal of Geophysics. 1995b. 38(6): 855-856 (in Chinese)

Wang L S, Li C and Yang C. The lithospheric thermal structure beneath Tarim Basin, Western China. Chinese Journal of Geophysics. 1996. 39(6): 794-803 (in Chinese)

Wang T G, He F Q, Li M J, et al. Alkyldibenzothiophenes: Molecular tracers for filling pathway in oil reservoirs. Chinese Science Bulletin. 2004. 49(22): 2399-2404 (in Chinese)

Wang T G, He F Q, Wang C J, et al. Oil filling history of the Ordovician oil reservoir in the major part of the Tahe Oilfield, Tarim Basin, NW China. Organic Geochemistry. 2008. 39(11): 1637-1646

Zhao W Z and Zhang G Y. Passive Continental Margin Evolution and Petroleum Geology - A Case Study in Southwest Tarim Basin. Beijing: Petroleum Industry Press. 2007. 70-90 (in Chinese)

Zhou L, Zhao W Z and He D F. Petroleum Geology and Exploration in Markit Slope, Tarim Basin. Beijing: Petroleum Industry Press. 2006. 44-74 (in Chinese)

(Edited by Hao Jie) 